$\mathrm{Nr}$ 4(61), 2019, s. 229-241

https://doi.org/10.12797/Politeja.16.2019.61.13

Joanna Aleksandra RADOWICZ (D)

Politechnika Świętokrzyska

jradowicz@tu.kielce.pl

\title{
TOŻSAMOŚĆ NARODOWA SZKOTÓW W ZJEDNOCZONYM KRÓLESTWIE WIELKIEJ BRYTANII I IRLANDII PÓŁNOCNEJ
}

ABSTRACT Scottish National Identity in the United Kingdom of Great Britain and Northern Ireland

Scotland became part of the United Kingdom in 1707, when the Act of Union was signed by both the Scottish and English Parliaments. Even though Scots were then largely subordinated to the decisions taken by Westminster, they maintained a sense of independence. One of the most important elements of building Scottish national identity is their history, mainly based on ScottishEnglish relations and traditions that have been thought to be "invented" by intellectual elites in the eighteenth and nineteenth centuries. The aim of the article is to present Scottish national identity in comparison to historical conditions, with particular emphasis on Scottish-English relations.

Key words: Scottish national identity, Scotland, Scottish history

Słowa kluczowe: tożsamość narodowa Szkotów, Szkocja, historia Szkocji 


\section{WSTĘP}

Szkocja to region, który zajmuje jedną trzecią Wysp Brytyjskich i wraz z Walią, Anglią i Irlandią Północną tworzy Zjednoczone Królestwo Wielkiej Brytanii i Irlandii Północnej. Do terytorium Szkocji należy około 790 wysp, z czego zaledwie mniej więcej $10 \%$ jest zamieszkanych. Największymi grupami wysp są Szetlandy i Orkady na północy oraz Hebrydy na zachodzie, które obejmują Lewis, Harris, Barra, Skye i Mull ${ }^{1}$.

Na lądzie Szkocję można podzielić na trzy regiony: Highlands, czyli północną i górzystą część; Central Lowlands, czyli doliny rzek Clyde i Tay, oraz Southern Uplands, czyli wyżyny południowej Szkocji. Terytorium Szkocji zamieszkuje niewiele ponad 5 mln mieszkańców ${ }^{2}$. Highlands i Wyspy zajmują więcej niż połowę całkowitej powierzchni Szkocji

Jak zauważa Robert Wiszniowski: Charakterystyczna lokalizacja geograficzna, morski klimat, występujące dwie skrajności: wysokie góry i nieprzychylne Morze Pótnocne, Irlandzkie i Ocean Atlantycki, a także dzika przyroda i rozproszone skupiska osadnicze warunkowaty Szkotów jako naród .

Współczesna Szkocja, będąca częścią Zjednoczonego Królestwa Wielkiej Brytanii i Irlandii Północnej, zaczęła w XX w. walczyć o większą niezależność od władzy w Londynie. W 2014 r. Szkoci zdecydowali się na przeprowadzenie referendum niepodległościowego, które jednak zakończyło się niepowodzeniem. Za opuszczeniem Wielkiej Brytanii zagłosowało wówczas 44,7\% Szkotów ${ }^{5}$, co jednak świadczyło o dużym poparciu dla idei niepodległości Szkocji. 2016 rok przyniósł nowe wyzwanie, jakim jest Brexit. Większość Szkotów, bo aż 62\%, opowiedziało się przeciwko wyjściu z Unii Europejskiej. Za pozostaniem w strukturach unijnych głosowali przede wszystkim mieszkańcy największych miast szkockich: Glasgow (66,6\%) i Edynburga $(74,4 \%)^{6}$. Te wyniki pokazały, że Szkoci inaczej niż większość Brytyjczyków (za pozostaniem w Unii głosowali również mieszkańcy Irlandii Północnej) postrzegają swoje miejsce w Europie.

Celem artykułu jest przedstawienie tożsamości narodowej Szkotów na tle uwarunkowań historycznych, ze szczególnym uwzględnieniem relacji szkocko-angielskich.

Scotland in Short, [online] http://www.gov.scot/Resource/Doc/923/0010669.pdf, 10 IX 2017.

2 R. Wiszniowski, Przetomy państwa wspótczesnego. Przypadek Szkocji i Katalonii, Warszawa 2013, s. 55-56.

3 Scotland in Short...

4 R. Wiszniowski, Przetomy państwa wspótczesnego..., s. 55-56.

5 P. Otaola, S. Bory, Autonomies et Indépendances, Le nationalisme de XXIe siècles, Saint-Denis 2016, s. 72 .

6 BBC News, Local Results, [online] http://www.bbc.com/news/politics/eu_referendum/results/local/ g, 16 VIII 2017. 


\section{SZKOCJA JAKO CZĘŚĆ ZJEDNOCZONEGO KRÓLESTWA. UWARUNKOWANIA HISTORYCZNE}

W VI w. tereny dzisiejszej Szkocji zamieszkiwały grupy etniczne pochodzenia celtyckiego - Piktowie, Szkoci i Brytowie - oraz grupa pochodzenia germańskiego, czyli Anglowie 7 . W 843 r. król Szkotów Kenneth I MacAlpine objął tron Piktów i podporządkował sobie ich ziemie. W XI w. grupa narodowościowa Piktów przestała istnieć, nie przetrwała również ich kultura i język. Zachowały się jedynie piktyjskie nazwy miejscowości zawierające przedrostek „pit” oraz kamienie z ornamentami i motywami roślinnymi oraz postaciami ludzi i zwierząt ${ }^{8}$. Mimo że Piktowie stanowili liczniejszą grupę, to jednak elitę polityczną i kulturalną tworzyli przede wszystkim Szkoci i to ich język - gaelicki (Scottish Gaelic) - stał się językiem używanym w całym królestwie?.

To nowe królestwo Piktów i Szkotów nazywane było początkowo Pictavią, a od momentu panowania Donalda II Albą (piktyjskie Albyn). Natomiast nazwa „Szkocja” pojawia się dla tych terenów później, ponieważ jeszcze w XI w. Scotia kojarzona była z Irlandią, a Szkot był synonimem Irlandczyka ${ }^{10}$.

W XI w. na tronie Szkocji zasiadł król Malcolm III i wprowadził na dwór obyczaje angielskie. Szlachta szkocka, czyli głównie mieszkańcy nizin (Lowlands), uległa wpływom angielskim, zwiększył się również zasięg używania języka angielskiego jako języka elit. Anglicy rozwinęli również feudalny system rządów. Na terenach północnych, zamieszkiwanych przez szkockich górali (Highlands), utrwalały się zwyczaje celtyckie i język, przetrwał również klanowy system organizacji społecznej ${ }^{11}$.

Na przełomie XIII i XIV w. wybuchało również wiele konfliktów pomiędzy Anglikami i Szkotami, z których najbardziej znana jest wojna o niepodległość Szkocji. Konflikt rozpoczęła w 1290 r. śmierć ośmioletniej księżniczki Małgorzaty, jedynej spadkobierczyni króla szkockiego Aleksandra III. Szkocja pozostała wówczas bez władcy. $\mathrm{Na}$ tronie zasiadł Jan Balliol - zależny od króla Edwarda I. Jednak Balliol odmówił złożenia Anglii hołdu lennego, co stało się przyczyną najazdu angielskiego na ziemie szkockie, a sam król został najpierw uwięziony w Anglii, a następnie wygnany do Francji. Edward I chciał całkowicie podporządkować sobie ziemie szkockie i wszelkie przejawy oporu wobec władzy króla spotykały się z bezlitosnymi karami, dzięki czemu Edward zyskał przydomek „Młota na Szkotów”" ${ }^{2}$. Na terytorium Szkocji stacjonowały wojska angielskie. Lata 1286-1371 to okres szkockich walk o niepodległość i dominacji Anglików na tym terytorium. Na czele opozycji wobec Edwarda I stanął wówczas młody

T. Czapiewski, Ksztattowanie się systemu politycznego Szkocji, Szczecin 2011, s. 21.

$8 \quad$ S. Zabieglik, Zarys historii Szkocji do końca XVIII wieku, Gdańsk 1993, s. 7-23.

9 Tamże, s. 16.

10 Tamże, s. 24.

11 Tamże, s. 28.

12 Tamże, s. 47-56; T. Czapiewski, Ksztattowanie się systemu politycznego Szkocji..., s. 21-22. 
William Wallace. Dnia 11 września 1297 r. dowodzeni przez Wallace’a Szkoci odnieśli zwycięstwo nad Anglikami w bitwie pod Stirling ${ }^{13}$.

W 1306 r. na tronie szkockim zasiadł Robert Bruce, który 24 czerwca 1314 r. pokonał Anglików w bitwie pod Bannockburn. Od tego momentu Szkocja była całkowicie niepodległym państwem, a rocznica tej bitwy jest do dzisiaj ważnym świętem narodowym Szkotów ${ }^{14}$. Formalnie niepodległość Szkocji została uznana przez Anglików w 1328 r. traktatem w Northampton ${ }^{15}$. Po śmierci królowej angielskiej Elżbiety I Szkocja i Anglia w 1603 r. zostały związane unią personalną Jakuba I. W 1707 r. zawarta została pomiędzy obydwoma krajami unia realna, która miała stanowić równoprawne połączenie Królestwa Szkocji i Królestwa Anglii. Na mocy ustanowionego wówczas Act Of Union powstała Wielka Brytania, a Szkoci zostali w rzeczywistości podporządkowani władzom w Londynie ${ }^{16}$.

W latach 1715-1745 miały miejsce ostatnie przejawy oporu Szkotów wobec Anglików, czyli krwawo stłumione powstania jakobickie. Jakobitami (Jacobites) nazwano zwolenników odzyskania korony brytyjskiej przez potomków króla Jakuba VII Stuarta (w Anglii panującego jako Jakub II).

Szczególnie silne represje zastosowali Anglicy po ostatnim powstaniu jakobickim w 1745 r. Skierowane one były przede wszystkim w stronę członków klanów zamieszkujących górzyste tereny Szkocji. Ranni byli dobijani, a jeńcy sprzedawani na plantacje w Ameryce jako niewolnicy ${ }^{17}$. W 1747 r. ustanowiony został Heritable Jurisdictions Act, na mocy którego zniesiono tradycyjne prawa sądowe przyznane szefowi klanu szkockiego, a także zlikwidowano urząd dziedzicznego szeryfa w Szkocji ${ }^{18}$. System klanowy został zakazany, Szkotom zabroniono noszenia kiltu i tartanu, używania języka gaelickiego, a nawet grania na dudach. Przywilej noszenia narodowego stroju szkockiego przysługiwał tylko członkom szkockich regimentów górskich, stanowiących część regularnej armii brytyjskiej. Represje, z jakimi spotkali się wówczas Szkoci, zahamowały opór górali wobec Anglików ${ }^{19}$.

13 A. Lyon, The English Parliament, [w:] The Edinburgh Companion to the History of Democracy, red. B. Isakhan, S. Stockwell, Edinburgh 2012, s. 169. and Bruce, Alford 1999, s. 148.

16 W. Ferguson, Scotland's Relations with England: A Survey to 1707, Edinburgh 1994, s. 254-265; M. Guibernau, Nationalism without States, [w:] The Oxford Handbook of the History of Nationalism, red. J. Breuilly, Oxford 2013, s. 598.

17 Ł.G. Burak, Ewolucja szkockiej tożsamości narodowej w Zjednoczonym Królestwie Wielkiej Brytanii, [online] http://www.kulturaihistoria.umcs.lublin.pl/archives/1869, 8 IX 2017.

18 J.W. Cairns, Historical Introduction, [w:] A History of Private Law in Scotland, vol. I, red. K. Reid, R. Zimmerman, Oxford 2000, s. 148.

19 Ł.G. Burak, Ewolucja szkockiej tożsamości... 


\section{TOŻSAMOŚĆ NARODOWA SZKOTÓW W ZJEDNOCZONYM KRÓLESTWIE WIELKIEJ BRYTANII I IRLANDII PÓŁNOCNEJ}

Szkoci w zawartym w 1707 r. Act Of Union otrzymali spore gwarancje niezależności w systemie prawnym, kwestiach Kościoła prezbiteriańskiego (Kirk) oraz systemu edukacji ${ }^{20}$. To zaważyło na tym, że Szkoci, będąc obywatelami Wielkiej Brytanii, nie poddali się dominacji władz w Londynie i zachowali poczucie niezależności.

Co istotne, nie tylko Szkoci zachowali poczucie odrębności w ramach Zjednoczonego Królestwa. Bowiem cała Wielka Brytania charakteryzuje się współwystępowaniem zarówno więzi ogólnopaństwowych, jak i więzi narodowych społeczności będących częściami Zjednoczonego Królestwa (Szkotów, Irlandczyków, Walijczyków, a także Anglików ${ }^{21}$. I jak zauważa David Stevenson: Naród jest swoja przesztościa i aby zrozumieć, co oznacza być Brytyjczykiem, konieczne jest branie pod uwage przesztości Szkocji, Irlandii oraz Walii, jak równiė̇ Anglii ${ }^{22}$.

Warto przedstawić ocenę Normana Daviesa, który uznał, że Zjednoczone Królestwo nie było jednak w stanie zharmonizować tożsamości wspólnot narodowych znajdujących się w jego ramach. Państwa narodowe powstają bowiem, zdaniem autora, gdy mają w momencie tworzenia określone instytucjonalne podstawy, jakimi są: jednolity system prawny, wspólna polityka kulturalna, wspólna historia czy jeden Kościół państwowy $^{23}$. W Wielkiej Brytanii brakowało tej jedności, widoczna była natomiast spora decentralizacja.

Jak zauważa Tadeusz Paleczny: Tożsamość, choć jest zjawiskiem uniwersalnym, relatywizuje się do kontekstu grupowego. Podobnie jak kultura, tożsamość opiera się na pochodzeniu etnicznym, rasowym, jezyku, religii, więzi terytorialnej ${ }^{24}$.Zdaniem T. Palecznego: Tożsamość nie może istnieć poza kontekstem grupowym ${ }^{25}$. Tożsamość to przede wszystkim poczucie przynależności do danej grupy, którą wyróżnia opozycja wobec innych grup i podział na „my” i „oni”, na „swoich” i „obcych”26.

Tożsamość jest zawsze „jakaś”, co powoduje, że towarzyszy jej zawsze przymiotnik; można zatem mówić o tożsamości narodowej, etnicznej, kulturowej, społecznej, regionalnej itp. ${ }^{27}$

20 M. Guibernau, Nationalism without States..., s. 598.

21 P. Rybicki, Więź spoteczna i jej przemiany, [w:] Socjologia. Lektury, red. P. Sztompka, M. Kucia, Kraków 2006, s. 140.

22 D. Stevenson, Twilight before Night or Darkness before Dawn? Interpreting Seventeenth-Century Scotland, [w:] Why Scottish History Matters, red. R. Mitchison, Edinburgh 1994, s. 47.

23 T. Czapiewski, Ksztattowanie sie systemu politycznego Szkocji..., s. 68.

24 T. Paleczny, Socjologia tożsamości, Kraków 2008, s. 24-25.

25 Tamże, s. 25.

26 P. Załęski, Tożsamości kulturowe - wprowadzenie, [w:] Tożsamości kulturowe w Europie Zachodniej, red. P. Załęski, A. Siliwoniuk, Warszawa 2012, s. 191.

27 T. Paleczny, Socjologia tożsamości..., s. 23. 
Na potrzeby pracy warto przede wszystkim wyjaśnić pojęcie tożsamości narodowej, która przez Antoninę Kłoskowską definiowana jest jako zbiorowa samowiedza zbiorowości narodowej, jej samookreślenie, tworzenie wtasnego obrazu i cata zawartość, treść samowie$d z y$, a nie z zewnattrz konstruowany obraz charakteru narodu ${ }^{28}$. Pojęcie tożsamości narodowej współwystępuje z definicją narodu i koncepcją wspólnoty narodowej. Naród może być pojmowany w kontekście politycznym, kulturowym lub etnicznym. Joanna Kurczewska naród określa jako ponadstanowa, ponadwarstwowa i ponadklasowa wspólnotę o charakterze historycznym, wyposażona w pewne cechy obiektywne (np.: terytorium, państwo, języ) i przymioty subiektywne, wyrażające się w świadomości przynależności do wspólnoty ${ }^{29}$. Brytyjski socjolog Benedict Anderson podkreślił, że ludzie przede wszystkim identyfikują się z pojęciem narodu, który - jak to określił - jest „wspólnotą wyobrażoną"30. Warto zaznaczyć, że członkowie takiej wspólnoty często nie znają się wzajemnie, nie spotykają się i nic o sobie nie wiedzą, jednak mają poczucie przynależności do niej ${ }^{31}$. Ponadto wspólnota ta istnieje tak długo, jak długo ludzie wyobrażają sobie, że do niej należą.

Naturalnym zjawiskiem jest oczywiście, że człowiek ma zdolność do wielości poczucia przynależności do różnych grup czy wspólnot ${ }^{32}$.

W Szkocji zauważalne jest współwystępowanie jednocześnie poczucia bycia Szkotem, jak i Brytyjczykiem. Pierwsza kategoria odnosi się do tożsamości narodowej, druga nosi miano tożsamości państwowej. Poczucie przynależności do brytyjskości lub szkockości są regularnie badane w sondażach. Te dwie odmienne więzi w historii tego państwa miały różnorodne znaczenie i na przestrzeni lat ulegały zmianom. Do badania tożsamości narodowej wykorzystuje się tzw. pytanie Moreno (Moreno question): „Która z odpowiedzi najlepiej opisuje to, kim się czujesz (dosłownie: jak widzisz siebie "Which of these the best describes how you see yourself $)$. Respondenci mają do wyboru kilka odpowiedzi na to pytanie, a mianowicie, że czują się: Szkotem, nie Brytyjczykiem (Scottish not British); bardziej Szkotem niż Brytyjczykiem (more Scottish than British); tak samo Szkotem, jak i Brytyjczykiem (equally Scottish and British); bardziej Brytyjczykiem niż Szkotem (more British than Scottish); Brytyjczykiem, nie Szkotem (British not $S c o t t i s h)^{33}$. Na tej podstawie dokonuje się oceny poczucia tożsamości narodowej badanych. Jak zauważa David McCrone, można mieć zastrzeżenie do tych pytań, przede wszystkim z powodu tego, czy respondenci prawidłowo je interpretowali, ale jednak są one wykorzystywane do badania poczucia „szkockości” i „brytyjskości”. Badania przeprowadzane są każdego roku i co roku wykazywały wśród Szkotów tendencję do bycia bardziej Szkotami, a nie Brytyjczykami lub Szkotami bardziej niż Brytyjczykami.

28 A. Kłoskowska, Kultury narodowe u korzeni, Warszawa 1996, s. 99.

29 J. Kurczewska, Naród, [w:] Encyklopedia socjologii, t. 2, red. Z. Bokszański, Warszawa 1999, s. 288.

30 D. McCrone, Do czego przynależymy?, „Kultura Liberalna” nr 297, 16 II 2014, [online] http://kulturaliberalna.pl/2014/09/16/czego-przynalezymy/, 12 IX 2017.

31 B. Anderson, Wspólnoty wyobrażone. Rozważania o źródtach i rozprzestrzenianiu się nacjonalizmu, Warszawa-Kraków 1997, s. 19.

32 N. Davies, Wyspy. Historia, przeł. E. Tabakowska, Kraków 2003, s. 909-911; T. Czapiewski, Ksztattowanie sie systemu politycznego Szkocji..., s. 68.

33 D. McCrone, Understanding Scotland, The Sociology of a Nation, London-New York 2001, s. 160. 
Jednak, co ciekawe, mniej więcej od 2012 r., z niewielkimi wahaniami, wyniki „pytania Moreno" wskazują na niewielki wzrost poczucia bycia tak samo Szkotem, jak i Brytyjczykiem $^{34}$. W 2016 r. 29\% badanych odpowiedziało, że czuje się tak samo Szkotami, jak Brytyjczykami, natomiast 28\% udzieliło odpowiedzi: „czuję się Szkotem, nie Brytyjczykiem” oraz 28\%: „czuję się Szkotem bardziej niż Brytyjczykiem”. Należy jednak zwrócić uwagę, że odpowiedzi „czuję się bardziej Brytyjczykiem niż Szkotem” oraz „czuję się Brytyjczykiem, nie Szkotem” wyniosły w 2016 r. odpowiednio 4 i 6\% i utrzymują się na tym samym poziomie od wielu lat ${ }^{35}$.

Jednym z najważniejszych elementów budowania tożsamości narodowej jest dla Szkotów ich historia. Warto przytoczyć słowa Jamesa A. Froude’a: Żaden naród w Europie nie może patrzeć z większa doprawdy duma na swoja przesztość niż Szkoci, i żaden mtody Szkot nie powinien ujawniać ignorancji wobec tego, co jest przesztością ${ }^{36}$.

W historii Szkocji na pierwszym planie pojawiają się ciągłe walki o niepodległość. Bardzo silny w tej tradycji jest przede wszystkim aspekt walki z Anglikami, którzy przez wieki starali się podporządkować sobie Szkotów. Na tej podstawie stworzona została tożsamość negatywna, która jednocześnie współwystępuje z wcześniej wspominanym poczuciem brytyjskości. Antyangielskość wpisana jest w tradycję narodową Szkotów i podkreślana podczas ważnych wydarzeń sportowych oraz świąt, które są przeważnie rocznicami wygranej lub przegranej bitwy z Anglikami. Szkoci świętują rocznicę zwycięstwa Roberta Bruce’a pod Bannockburn oraz inne ważne bitwy ${ }^{37}$. Zdaniem D. McCrone’a konflikt z Anglikami przyczynił się do zjednoczenia Szkotów w jeden naród w obliczu tego wspólnego zagrożenia ${ }^{38}$.

W budowaniu tradycji narodowej Szkotów duże znaczenie miało odkrycie w XVIII i XIX w. przez elity intelektualne Szkocji tradycji ludowych górali szkockich. Wywodzące się z kultury celtyckiej symbole Highlands, czyli wyżyn, zostały uznane później za dziedzictwo całego narodu szkockiego ${ }^{39}$. Popularyzacja tych symboli miała na celu przede wszystkim odróżnienie Szkotów od Anglików. To właśnie - jak ją nazwało wielu badaczy - „wynaleziona” tradycja oraz mity są istotną częścią zbiorowej pamięci historycznej Szkotów ${ }^{40}$.

Tożsamość narodowa Szkotów, jak wspomniane zostało wcześniej, opiera się głównie na tożsamości obywatelskiej. Dwudziestowieczne odrodzenie narodowe Szkotów

34 „Moreno" national identity, [online] http://whatscotlandthinks.org/questions/moreno-national-ident ity-5, 10 IX 2017.

„Moreno" national identity, YouGov, [online] http://whatscotlandthinks.org/questions/moreno-na tional-identity-yougov, 10 IX 2017.

36 A. Nowakowska-Dryk, Unia realna angielsko-szkocka w ujęciu historiografii szkockiej XX w. Od kontynuacji do rewizji, „Acta Universitatis Lodziensis. Folia Historica” 2001, nr 70, s. 168.

37 A. Kulpa, Tradycja wynaleziona i obywatelskość w tożsamości Szkotów, [w:] Tożsamości kulturowe w Europie Zachodniej, red. P. Załęski, A. Siliwoniuk, Warszawa 2012, s. 195-196.

38 D. McCrone, Understanding Scotland..., s. 156.

39 A. Kulpa, Tradycja wynaleziona i obywatelskość w tożsamości Szkotów..., s. 191-192.

40 B. Prabucki, Sport jako element tożsamości etnicznej. Antropologiczna analiza na przyktadzie Szkotów, „Etnografia Polska” 2012, t. 56, z. 1-2, s. 132-133. 
nastąpiło przede wszystkim w związku ze zmianami społeczno-ekonomicznymi ${ }^{41}$. Nie bez znaczenia pozostaje jednak również kultura i tradycja szkocka. Mimo że niektórzy badacze określają tradycje Szkotów „wymyślonymi” czy „wynalezionymi” - jak na przykład Eric Hobsbawm czy Hugh Trevor-Roper ${ }^{42}$ - to nie oznacza jednak, że nie są one prawdziwe. Ponadto wpisały się one w kulturę szkocką i stanowią ważny element identyfikacji Szkotów z własnym narodem.

Kojarzone z kulturą i tradycją Szkotów tartan (szkocka kratka) czy kilt są rozpoznawalne na całym świecie i przeniesione zostały również do kultury masowej. Kilt to noszony przez mężczyzn tweedowy strój w kratę, gdzie każdy klan ma swój oficjalny i niepowtarzalny wzór. Szkocka kratka stała się ważnym symbolem szkockości także dlatego, że odróżniała Szkotów od Anglików. Ponadto, kiedy po drugim powstaniu jakobickim parlament brytyjski prawnie zakazał używania szkockich symboli narodowych, tartan stał się symbolem oporu wobec opresyjnej władzy Anglików ${ }^{43}$.

Narodowym instrumentem Szkotów są dudy, które pochodzą ze Szkocji i stały się instrumentem znanym na całym świecie. Dudy uznawane są również za element tradycji „wymyślonej”, ale stanowią, podobnie jak inne z tych elementów, silny i mocno rozpoznawalny symbol Szkocji ${ }^{44}$.

Ważną rolę w budowaniu szkockości pełni również golf, który kojarzony jest stereotypowo z mieszkańcem Highlands ubranym w kilt. John Lowerson określił go jako sport, który stał się elementem tworzenia obrazu Szkota na potrzeby reklamowania szkockości. Z jednej strony stał się on symbolem tego, co szkockie, z drugiej zaczął przynosić znaczne dochody jako szkocka atrakcja turystyczna ${ }^{45}$.

Językami używanymi w Szkocji są Scottish Gaelic, czyli gaelicki, używany głównie przez mieszkańców wysp i wyżyn, oraz szkocki (Scots), którym wielu Szkotów posługuje się w codziennej komunikacji. Szkocki gaelicki wywodzi się z grupy języków celtyckich i w samej Szkocji posługuje się nim bardzo mała liczba osób (ok. 60 tys.). W codziennej komunikacji posługują się nim mieszkańcy Hebryd. Prowadzone są także działania na rzecz zachowania języka gaelickiego i jego promocji. Na wyspie Skye w college'u Sabhal Mòr Ostaig kształci się młodych ludzi w Scottish Gaelic, a od 1891 r. propagatorem języka i kultury gaelickiej jest Towarzystwo Comunn Gàidhealach ${ }^{46}$. W celu zachowania tego języka stworzony został również Narodowy Plan na rzecz Gaelickiego (National Plan for Gaelic) ${ }^{47}$.

\footnotetext{
A. Kulpa, Tradycja wynaleziona i obywatelskość w tożsamości Szkotów..., s. 189-190.

42 Pojęcie tradycji wynalezionych opisane zostało w książce: The Invention of Tradition, red. E. Hobsbawm, T. Ranger, Cambridge 2012.

43 F. Myuhtar-May, Identity, Nationalism, and Cultural Heritage under Siege, Leiden-Boston 2014, s. 21.

44 S. McKerrell, Focus: Scottish Traditional Music, New York-London 2016, s. 31.

45 B. Prabucki, Sport jako element tożsamości etnicznej..., s. 132-133.

46 A. Kulpa, Tradycja wynaleziona i obywatelskość w tożsamości Szkotów..., s. 197-200.

47 Attitudes Towards the Gaelic Language, Scottish Government Social Research, August 2011, [online] http://dera.ioe.ac.uk/10455/1/0120038.pdf, s. 4, 12 IX 2017.
} 
Drugi język narodowy Szkotów - Scots - jest natomiast językiem germańskim, spokrewnionym z językiem angielskim. Język ten jest używany przez większą część Szkotów, jednak charakteryzuje go brak określonej gramatyki i bardzo duża liczba dialektów ${ }^{48}$.

Jak zauważa Roman Szul, język gaelicki i szkocki mogą współcześnie pełnić rolę symboliczną w budowaniu tożsamości narodowej Szkotów i pozwalają im odróżniać się od Anglików ${ }^{49}$. Nie są jednak językami odgrywającymi istotną rolę w identyfikacji narodowej Szkotów.

Podejmując problem niezależności Szkocji, podkreśla się przede wszystkim rolę Kościoła prezbiteriańskiego, który miał nie tylko znaczenie religijne, ale również edukacyjne, społeczne i kulturowe ${ }^{50}$. Kirk był zawsze jednym z filarów utrzymania i budowania tożsamości narodowej Szkotów ${ }^{51}$.

Szkoci szczycą się wybitnymi przedstawicielami nauki i kultury. Można im przyznać rację, bo kiedy przyjrzymy się szkockim twórcom i naukowcom, to ich lista jest rzeczywiście imponująca. Wśród wielkich szkockich naukowców warto wymienić bowiem Alexandra Grahama Bella, twórcę telefonu, Jamesa Clerka Maxwella czy Aleksandra Fleminga. Znajdą się na tej liście również wielcy myśliciele, jak Adam Smith czy David Hume. A sławni szkoccy pisarze to z kolei: sir Arthur Conan Doyle, Lord George Byron, Robert Louis Stevenson, a także Joanne Rowling ${ }^{52}$. Szkoci zwracają szczególną uwagę na swoich wielkich rodaków, przede wszystkim dlatego, że w świadomości innych społeczeństw bardzo często odbierani są ogólnie jako Brytyjczycy, a nawet czasem jako Anglicy.

Zatem będąc częścią Zjednoczonego Królestwa, Szkoci nie ulegli asymilacji, a wręcz w XX w. można zauważyć wzrost nastrojów niepodległościowych w tym regionie. Bardzo istotnym elementem budowania szkockiej niezależności był proces dewolucji, którego początki sięgają lat 70. XX w. Dewolucja to decentralizacja wtadzy, która oznacza przekazanie dotychczasowych funkcji wykonywanych przez ministrów i parlament na rzecz organu pochodzacego z wyborów opartych na kryterium geograficznym ${ }^{53}$. Można również przytoczyć definicję Tomasza Czapiewskiego, który określa dewolucję jako występujący w Zjednoczonym Królestwie proces delegacji kompetencji przez organy centralne na rzecz organów reprezentujacych terytoria Szkocji, Walii oraz Irlandii Pótnocnej ${ }^{54}$.

W latach 70. ubiegłego wieku dewolucja nie została przeprowadzona. Pomimo że większość Szkotów opowiedziała się za zmianami dewolucyjnymi, nie został spełniony

A. Kulpa, Tradycja wynaleziona i obywatelskość w tożsamości Szkotów..., s. 197-200.

R. Szul, Jezzyk, naród, państwo. Język jako zjawisko polityczne, Warszawa 2009, s. 259.

50 A. Kulpa, Tradycja wynaleziona i obywatelskość w tożsamości Szkotów..., s. 197. Attitudes Towards the Gaelic Language..., s. 4.

51 M.S. Leith, D.P.J. Soule, Political Discourse and National Identity in Scotland, Edinburgh 2011, s. 23.

52100 Famous Scottish People, [online] http://www.biographyonline.net/british/top-100-scottish.html, 15 IX 2017.

53 V. Bogdanor, Devolution in the United Kingdom, Oxford 1999, s. 2.

54 T. Czapiewski, Ksztattowanie sie systemu politycznego Szkocji..., s. 11. 
wymóg frekwencji 40\% uprawnionych do głosowania ${ }^{55}$. Późniejsze 18-letnie rządy Partii Konserwatywnej (1979-1997) zahamowały wszelkie aspiracje do niezależności Szkocji ${ }^{56}$. Dopiero wygrana Partii Pracy w 1997 r. umożliwiła dalszy proces dewolucji $^{57}$. Szkoci w przeprowadzonym w tym samym roku referendum opowiedzieli się za utworzeniem Parlamentu Szkockiego (74\% za) oraz za tym, żeby parlament posiadał kompetencje do zmiany wysokości podatków $(63 \%)^{58}$. W 1998 r. parlament brytyjski przyjął większością głosów Scotland Act, na mocy którego powstały organy szkockiej władzy ustawodawczej i wykonawczej: Parlament Szkocki (Holyrood) oraz szkocki rząd ${ }^{59}$.

Co istotne, proces dewolucji nie zahamował aspiracji niepodległościowych Szkotów. Zdaniem niektórych badaczy, dewolucja wręcz wzmocniła tendencje separatystyczne w Szkocji. Pomimo że w referendum przeprowadzonym w 2014 r. większość Szkotów opowiedziała się za pozostaniem w Zjednoczonym Królestwie, to jednak było to zaledwie 55\% obywateli i najprawdopodobniej o wyniku przesądziły bardziej kwestie ekonomiczne i bezpieczeństwa niż małe poparcie dla idei niepodległości.

\section{ZAKOŃCZENIE}

Mimo że wiele elementów kultury szkockiej zostało, zdaniem wielu badaczy, „wynalezionych", stanowią one istotny aspekt pamięci historycznej, a współcześni Szkoci utożsamiają się z tymi symbolami i mają one duży wpływ na budowanie ich poczucia tożsamości narodowej.

Zdaniem Davida McCrone’a, Szkoci, podobnie jak Katalończycy czy mieszkańcy prowincji Quebec, są społeczeństwem postmodernistycznym, dla którego tożsamość narodowa to bardziej tożsamość obywatelska niż etniczna ${ }^{60}$. Według niego życie polityczne Szkotów koncentruje się przede wszystkim na poziomie lokalnym. Młodzi Szkoci identyfikują się bardziej z sąsiednim miastem niż narodem czy państwem. Jak zauważa McCrone: Motorem przemian $w$ myśleniu o narodzie szkockim sa ludzie mtodzi. To oni najsilniej artykutuja postulaty zwiększenia autonomii, tworzac oddolne gtównie miejskie - ruchy spoteczne. W ten sposób daja wyraz chęci kontrolowania swojego życia, nadawania mu takiego ksztaltu, o jakim nigdy nie marzyli ich dziadkowie $e^{61}$.

55 W referendum wzięło udział zaledwie 33\% wyborców. V. Bogdanor, The People and the Party System. The Referendum and the Electoral Reforms in British Politics, Cambridge 1981, s. 56-59.

C. Pilkington, Devolution in Britain Today, Manchester-New York 2002, s. 65-66; S. Zabieglik, Historia Szkocji, Gdańsk 2000, s. 320.

57 P. Surridge, A Better Union?, [w:] Has Devolution Delivered?, red. C. Bromley, J. Curtice i in., Edinburgh 2006, s. 4 .

58 D. Denver i in., Scotland Decides, London-New York 2006, s. 50.

59 M.S. Leith, D.P.J. Soule, Political Discourse..., s. 34.

60 A. Kulpa, Tradycja wynaleziona i obywatelskość w tożsamości Szkotów..., s. 189-190.

61

D. McCrone, Do czego przynależymy?... 
Obecnie Szkoci muszą zmierzyć się ze zmianami, jakie niesie ze sobą procedura Brexitu. Czują się oni częścią Zjednoczonego Królestwa, jednak są również zwolennika$\mathrm{mi}$ integracji europejskiej. Dla Szkocji członkostwo w Unii Europejskiej było bardzo korzystne. Szkoci skorzystali na dofinasowaniu z funduszy unijnych oraz rozwinęli się dzięki otwartemu rynkowi Unii Europejskiej.

Nacjonaliści szkoccy, w tym rządząca Szkocka Partia Narodowa, zaczęli deklarować konieczność przeprowadzenia nowego referendum na temat opuszczenia Zjednoczonego Królestwa. Ze względu na fakt, że władze w Londynie bardzo zdecydowanie odrzuciły taką możliwość w czasie procesu wychodzenia z Unii Europejskiej, Szkoci zapowiedzieli, iż po zakończeniu Brexitu konieczne będzie jednak ponowne referendum na temat niepodległości Szkocji ${ }^{62}$. Czy Szkoci zdecydują się w końcu opuścić Zjednoczone Królestwo i stworzyć niepodległe państwo? Na pewno będzie wpływało na to bardzo wiele czynników. $Z$ jednej strony znaczącą rolę mogą odegrać nastroje niepodległościowe i potrzeba całkowitej suwerenności Szkocji, z drugiej Szkoci są jednak przywiązani do brytyjskości i Korony. Poza tym istotną rolę w podejmowaniu decyzji przez Szkotów będą miały uwarunkowania ekonomiczne, które po opuszczeniu Unii Europejskiej przez Wielką Brytanię zapewne ulegną istotnym zmianom.

\section{BIBLIOGRAFIA}

100 Famous Scottish People, [online] http://www.biographyonline.net/british/top-100-scot tish.html.

Anderson B., Wspólnoty wyobrażone. Rozważania o źródtach i rozprzestrzenianiu się nacjonalizmu, przeł. S. Amsterdamski, Warszawa-Kraków 1997.

Attitudes Towards the Gaelic Language, Scottish Government Social Research, August 2011, [online] http://dera.ioe.ac.uk/10455/1/0120038.pdf.

BBC News, LocalResults, [online] http://www.bbc.com/news/politics/eu_referendum/results/ local/g.

Bogdanor V., Devolution in the United Kingdom, Oxford 1999.

Bogdanor V., The People and the Party System. The Referendum and the Electoral Reforms in British Politics, Cambridge 1981.

Brown M., Bannockburn: The Scottish War and the British Isles, 1307-1323, Edinburgh 2008, https://doi.org/10.3366/edinburgh/9780748633326.001.0001.

Burak Ł.G., Ewolucja szkockiej tożsamości narodowej w Zjednoczonym Królestwie Wielkiej Brytanii, [online] http://www.kulturaihistoria.umcs.lublin.pl/archives/1869.

Cairns J.W., Historical Introduction, [w:] A History of Private Law in Scotland, vol. I, red. K. Reid, R. Zimmerman, Oxford 2000, https://doi.org/10.1093/acprof:oso/978019826 7782.003.0002.

62 Nicola Sturgeon shelves second Scottish independence referendum, „The Guardian”, [online] https:// www.theguardian.com/politics/2017/jun/27/nicola-sturgeon-shelves-second-independencereferendum, 10 IX 2017. 
Crome S., Scotland's First War of Independence. A Chronicle of the Struggle Fought and Won by Wallace and Bruce, Alford 1999.

Czapiewski T., Ksztattowanie się systemu politycznego Szkocji, Szczecin 2011.

Davies N., Wyspy. Historia, przeł. E. Tabakowska, Kraków 2003.

Denver D. i in., Scotland Decides, London-New York 2006.

Ferguson W., Scotland's Relations with England: A Survey to 1707, Edinburgh 1994.

Guibernau M., Nationalism without States, [w:] The Oxford Handbook of the History of Nationalism, red. J. Breuilly, Oxford 2013, https://doi.org/10.1093/oxfordhb/ 9780199209194.013.0030.

Kurczewska J., Naród, [w:] Encyklopedia socjologii, t. 2, red. Z. Bokszański, Warszawa 1999.

Kłoskowska A., Kultury narodowe u korzeni, Warszawa 1996.

Kulpa A., Tradycja wynaleziona i obywatelskość w tożsamości Szkotów, [w:] Tożsamości kulturowe $w$ Europie Zachodniej, red. P. Załęski, A. Siliwoniuk, Warszawa 2012.

Leith M.S., Soule D.P.J., Political Discourse and National Identity in Scotland, Edinburgh 2011. Lyon A., The English Parliament, [w:] The Edinburgh Companion to the History of Democracy, red. B. Isakhan, S. Stockwell, Edinburgh 2012.

McCrone D., Do czego przynależymy?, „Kultura Liberalna” nr 297, 16 II 2014, [online] http:// kulturaliberalna.pl/2014/09/16/czego-przynalezymy.

McCrone D., Understanding Scotland. The Sociology of a Nation, London-New York 2002, https://doi.org/10.4324/9780203414927.

McKerrell S., Focus: Scottish Traditional Music, New York-London 2016, https://doi.org/ $10.4324 / 9781315814995$.

'Moreno' national identity, YouGov, [online] http://whatscotlandthinks.org/questions/morenonational-identity-yougov.

Myuhtar-May F., Identity, Nationalism, and Cultural Heritage under Siege, Leiden-Boston 2014, https://doi.org/10.1163/9789004272088.

Nicola Sturgeon shelves second Scottish independence referendum, „The Guardian”, [online] https://www.theguardian.com/politics/2017/jun/27/nicola-sturgeon-shelves-secondindependence-referendum.

Nowakowska-Dryk A., Unia realna angielsko-szkocka $w$ ujęciu historiografii szkockiej XX w. Od kontynuacji do rewizji, „Acta Universitatis Lodziensis. Folia Historica” 2001, nr 70, s. 167-206.

Otaola P., Bory S., Autonomies et Indépendances, Le nationalisme de XXIe siècles, Saint-Denis 2016.

Paleczny T., Socjologia tożsamości, Kraków 2008.

Pilkington C., Devolution in Britain Today, Manchester-New York 2002.

Prabucki B., Sport jako element tożsamości etnicznej. Antropologiczna analiza na przyktadzie Szkotów, „Etnografia Polska” 2012, t. 56, z. 1-2, s. 121-142.

Rybicki P., Więź spoteczna i jej przemiany, [w:] Socjologia. Lektury, red. P. Sztompka, M. Kucia, Kraków 2006.

Scotland in Short, [online] http://www.gov.scot/Resource/Doc/923/0010669.pdf.

Stevenson D., Twilight before Night or Darkness before Dawn? Interpreting Seventeenth-Century Scotland, [w:] Why Scottish History Matters, red. R. Mitchison, Edinburgh 1994. 
Surridge P., A Better Union?, [w:] Has Devolution Delivered?, red. C. Bromley, J. Curtice i in., Edinburgh 2006, https://doi.org/10.3366/edinburgh/9780748622467.003.0003.

Szul R., Jezzyk, naród, państwo. Jezyk jako zjawisko polityczne, Warszawa 2009.

Wiszniowski R., Przetomy państwa wspótczesnego. Przypadek Szkocji i Katalonii, Warszawa 2013. Zabieglik S., Historia Szkocji, Gdańsk 2000.

Zabieglik S., Zarys historii Szkocji do końca XVIII wieku, Gdańsk 1993.

Joanna Aleksandra RADOWICZ - doktor nauk politycznych, absolwentka Uniwersytetu Jagiellońskiego oraz Akademii Świętokrzyskiej (obecnie Uniwersytet Jana Kochanowskiego w Kielcach). W 2010 r. uzyskała stopień doktora nauk humanistycznych w zakresie nauk o polityce w Instytucie Studiów Politycznych Polskiej Akademii Nauk w Warszawie. W 2012 r. ukończyła studia podyplomowe na kierunku Socjologia w Collegium Civitas w Warszawie. Od 2013 r. adiunkt na Wydziale Zarządzania i Modelowania Komputerowego w Politechnice Świętokrzyskiej, a od 2014 r. Wydziałowy Koordynator Programu Erasmus+. Obszary zainteresowań naukowych: tożsamość narodowa Szkotów, separatyzm szkocki, wielokulturowość w Wielkiej Brytanii. 